\title{
DEMO(N)S DAN KRATOS: \\ Kritik Terhadap Praktik Demokrasi dari Kacamata Kekristenan
}

\section{Yoshua Budiman Harahap}

\author{
Sekolah Tinggi Filsafat Teologi, Jakarta \\ Jl. Proklamasi No. 27, 10320, Jakarta Pusat \\ yoshua.harahap@stftjakarta.ac.id
}

\begin{abstract}
Democracy is often glorified as the modern language of an open government, making room for differences, and advocating justice. Primarily when power lays in the hands of the people and not only in several people. This idea was parallel to Christian values. However, behind this noble idea, democracy contains a problem, namely, when it only perpetuates the power of a few people. On behalf of the people, the ruler's agenda continues to be maintained because democracy opens up opportunities for abuse of power. Demos and kratos easily slip into demons and kratos. This article aims to criticize the practice of contemporary democracy and, at the same time, seeking gaps for the Church's contribution to maintaining democracy as a tool for flourishing humanity. To achieve that, I suggested three concepts: the Church as a public church, the Church as a counter-culture, and the Church as a liberating community. Through it, the Church can and is encouraged to be active in maintaining democratic values.
\end{abstract}

Keywords: Democracy, Demos and kratos, Demons and kratos, Public Church, Counterculture, the community of liberation.

\begin{abstract}
Abstrak
Tidak jarang demokrasi diagungkan sebagai bahasa modern dari pemerintahan yang terbuka, memberi ruang bagi perbedaan, dan menjunjung keadilan. Terutama ketika kekuasaan tidak dipegang oleh sebagian orang saja, melainkan di tangan rakyat. Sebuah ide yang sejajar dengan nilai-nilai kekristenan. Namun demikian, di balik gagasan adiluhung tersebut, demokrasi ternyata mengandung permasalahan pelik, yaitu ketika ia justru melanggengkan kekuasaan segelintir orang saja. Atas nama rakyat, agenda kekuasaan terus terpelihara karena demokrasi justru membuka peluang bagi penyalahgunaan kekuasaan. Demos dan kratos berubah menjadi demons dan kratos, terutama ketika kekuasaan yang dipegang segelintir orang cenderung menjadi kekuasaan yang zalim. Artikel ini mencoba mengkritisi praktik demokrasi tersebut dan juga melihat celah sumbangsih gereja dan kekristenan dalam menjaga demokrasi tetap sebagai reka kehidupan bersama dari, untuk, dan oleh rakyat. Tiga konsep yang ditawarkan adalah gereja sebagai gereja publik, gereja sebagai tenaga penyeimbang, dan gereja sebagai komunitas pembebas menjadi penting karena melaluinya, gereja bisa dan didorong untuk ikut aktif dalam menjaga nilai-nilai demokrasi.
\end{abstract}

Kata Kunci: Demokrasi, Demos dan kratos, Demons dan kratos, Gereja publik, Tenaga Penyeimbang, Komunitas Pembebas. 


\section{PENDAHULUAN}

Demokrasi sebagai sebuah tata kelola sebuah masyarakat telah diakui dan diadopsi oleh banyak negara sebagai sebuah sistem yang mampu menampung aspirasi setiap pihak sembari mengedepankan kemajuan. Demokrasi senantiasa dieluelukan sebagai tanda kemajuan sebuah negara bahkan menjadi sebagai penanda kemajuan peradaban sebuah bangsa. Dengan kata lain, demokrasi menjadi sebuah bahasa bersama akan pengakuan kemanusiaan bahwa kita diciptakan berbeda dan untuk itu penting dalam menghargai perbedaan itu sendiri. Kepelbagaian dan kemajemukan seakan direngkuh dalam praktik berdemokrasi.

Susan Welch, menempatkannya dengan tepat,

Democracy embraces conflict and competition just as it requires cooperation and a sense of community. A basic function of government is to establish the rules under which interests can compete. Thus, the essence of political culture is agreement on fundamental principles and on a common perception of the rights and obligations of citizenship and the rules for participating in the political process. These shared values reduce the strains produced by our differences and allow us to compete intensely on some issues while cooperating on others. ${ }^{1}$

Pendapat Welch di atas, ketika konflik dan kompetisi dilihat sebagai sesuatu yang natural dan sehat, hanya dapat terjadi dalam masyarakat yang telah melampaui perbedaan itu sendiri. Bahwa masyarakat sepakat kepentingan bersama dan common good perlu diusung oleh setiap unsur yang membentuk masyarakat. Kesatuan gerak demi mencapai cita-cita dan nilai-nilai bersama inilah yang menjadikan demokrasi sebagai tools yang menarik banyak pihak untuk menggunakannya.

Hal ini sejalan dengan akar kata demokrasi itu sendiri, yang berasal dari dua kata Yunani "demos" dan "kratos", yang masing-masing berarti "rakyat" dan "kekuasaan."2 Sebuah eu-topia yang digagas oleh peradaban kuno Roma dan Yunani akan sebuah kota yang adil dan merata bagi banyak orang. Pada benih pemikiran inilah demokrasi modern berakar, dan mendapat dukungan akan nilai-nilai kemanusiaan pada masa pencerahan dan membentuk masyarakat yang baru, seperti dikatakan oleh Campbell terkait demokrasi di Eropa, "grounded by enlightened 
optimism about progress, liberty, and human rights, modern Europeans reinvented their political, economic, and social institutions to reflect these new ideals."3

Demokrasi semakin berkembang terutama ketika totalitarianisme dan empirialisme telah kehilangan kharismanya sebagai sebuah sistem pemerintahan yang sehat. Menaruh kekuasaan pada segelintir orang adalah hal yang coba dihindari oleh masyarakat modern melalui demokrasi. Seperti yang juga ditunjukkan oleh Campbell dalam penelitiannya mengenai sejarah demokrasi di Eropa, mulai dari revolusi Prancis, kekejian Hitler, hingga demokrasi modern di abad 21. Bagi Campbell, demokrasi dan kesatuan menjadi satu-satunya harapan bagi Eropa yang telah menyaksikan dan mengalami sejarah kelam ketika kekuasaan dipegang oleh segelintir orang dan tidak ada satu kekuatan lainnya yang mampu meredamnya. ${ }^{4}$ Sayang, tesis Campbell ini seakan luluh ketika pada saat ini Eropa mengalami degradasi kesatuan dan kemampuan untuk menerima yang lain, yang berbeda. Fenomena Brexit adalah contoh fenomena mengerasnya nasionalisme dan meluruhnya identitas ke-eropa-an.

Ironisnya, demokrasi yang dibangun untuk memajukan kebaikan bersama (common good) tanpa menafikan hak-hak kelompok minoritas telah menjadi permainan segelintir elit politik. Ketika demokrasi menjadi elitokrasi atau meritrokrasi atau aristrokrasi atau bahkan plutokrasi. Memang, tidak secara terangterangan perubahan ini terjadi namun dalam praktiknya hal ini dapat dirasakan. Terutama dalam pemilihan kepala daerah atau pemilihan kepala pemerintahan, kekuasaan tidak terletak pada tangan pemerintah namun terletak pada partai dan elit politik. Demokrasi tidak lagi menjadi "demos-kratos" namun telah menjadi demonskratos, yaitu kekuasaan berada di tangan si jahat. Demokrasi tidak sedang melayani masyarakat sebagai pemegang kekuasaan namun melenggangkan kekuasaan segelintir orang, demi kekayaan dan penambahan kapital sekelompok kecil elit dan ini dilakukan dengan memakai konstitusi sebagai alatnya. Pada titik ini, kekristenan perlu hadir sebagai sebuah kritik sosial yang membangun masyarakat, karena tanpa kritik, agama hanyalah nilai yang mati dan seakan berada di ruang hampa. ${ }^{5}$ Bahwa demokrasi saat ini tidak lagi sejalan dan seirama dengan kekristenan sebagai sebuah nilai yang memperjuangkan kehidupan yang layak bagi setiap orang tanpa pandang 
bulu. Kekristenan berakar pada pengakuan bahwa "all men are created equal" meminjam isitilah dari Martin Luther King Jr. ${ }^{6}$

Untuk itu, artikel ini - sebagai sebuah reka teologi - mencoba untuk melihat kembali demokrasi dari kaca mata kekristenan. Bukan demokrasi dalam arti teori dan filosofis namun praktik dan refleksi dibaliknya. Bahwa sebagai sebuah nilai luhur yang dihidupi oleh umat, kekristenan tidak boleh dan tidak dapat hanya bertahan dalam ruang-ruang tertutup dan ibadah yang menyentuh hati, namun iman Kristen perlu menjadikan dirinya sebagai "pewarna" bahkan "ruh" penggagas akan kehidupan kesederajatan yang lebih baik. Saya berpendapat bahwa demokrasi pada saat ini telah melenceng dari cita-cita awalnya, sebagai sebuah sistem yang memastikan bahwa kekuasaan ada di tangan rakyat. Penyimpangan ini telah terjadi secara sistemik dan dengan sengaja dipelihara. Penyalahgunaan kekuasaan dalam sistem demokrasi pada saatnya akan mencederai kehidupan bersama bangsa Indonesia. Untuk itu, saya akan mencoba memberikan kritik terhadap demokrasi sebagai sebuah korupsi berjemaah yang telah berurat-akar dalam kehidupan bangsa ini. Bahwa demokrasi saat ini hanya melayani kepentingan segelintir orang saja tanpa memedulikan sebagian besar rakyat Indonesia. Ini menjadi bagian pertama.

Pada "retakan" demokrasi inilah kemudian kekristenan sebenarnya dapat memberikan kontribusi yang nyata. Ibarat sebuah vas yang retak, maka cahaya kekristenan dapat masuk dan menerangi relung-relung gelap yang selama ini ada di dalamnya. Kekristenan pada dirinya, sejatinya memiliki nilai-nilai universal yang merengkuh setiap kelompok dan memanusiakan manusia. Bahwa tersimpan DNA kesederajatan di dalam agama Kristen yang dapat ditularkan kepada praktik demokrasi di Indonesia. Namun ini akan menjadi bagian ketiga karena sebelum sampai di sana, maka saya perlu menyediakan "jembatan hermeneutika" mengenai bagaimana agama dan iman dapat berpartisipasi dalam kehidupan publik. Tulisan Miroslaf Volf, Rowan Williams dan Dietrich Bonhoeffer menjadi salah satu acuan penting ketika ketiganya berbicara mengenai "public faith" sebagai sebuah konsekuensi yang tidak terelakkan dari iman Kristen. "Jembatan hermeneutika" akan menjadi bagian kedua dari tulisan ini. 


\section{METODE PENELITIAN}

Natur dari artikel ini adalah sebuah eksplorasi kualitatif dengan memanfaatkan kajian pustaka secara ekstensif. Dalam melakukan eksplorasi tersebut, tulisan ini dipandu dengan dua pendekatan, yaitu teologis-analitis dan reflektifkonstruktif. Pendekatan teologis-analitis berarti tulisan ini hendak mencoba melakukan analisa kecenderungan praktik demokrasi di Indonesia serta konteks sosial-politik yang mengitarinya dari kacamata rumpun ilmu teologi. Sekalipun ada kemiripan penamaan, pendekatan ini perlu dibedakan dengan mazhab Teologi Analitis (Analytic Theology) yang menghasilkan nama-nama teolog terkemuka seperti Alvin Plantinga, Richard Swinburne, Peter van Inwagen, dan J.L. Mackie. Pendekatan reflektif-konstruktif berarti tulisan ini tidak berakhir pada sebuah analisa teologis semata, namun juga hendak menawarkan sebuah reka teologis yang kiranya dapat digagas dan diejawantahkan dalam kehidupan gereja maupun umat Kristen sebagai individu. Terutama sembari mengingat peran dan tanggung jawab gereja dan individu Kristen dalam kehidupan sosial-politik yang lebih luas di Indonesia.

\section{PEMBAHASAN}

\section{Demokrasi dalam Persimpangan}

"I don't care who does the electing, so long as I get to do the nominating."7 Petikan kalimat William M. Tweed ini menandai dan menunjukkan sebuah gejala sumir dari demokrasi, yaitu bahwa demokrasi yang terlihat sehat dan menjunjung tinggi suara rakyat, belum tentu benar adanya. Tweed tentu berbicara dalam konteks Amerika, yang memiliki sistem pemilu yang cukup berbeda dengan Indonesia. Namun, secara prinsip demokrasi terpimpin melalui perwakilan rakyat berupa MPR/DPR dan pemilihan langsung kepala daerah merupakan bentuk yang serupa dengan yang telah diungkapkan Tweed di atas. Bahwa dalam dunia demokrasi di mana rakyat memilih langsung pemimpinnya, belum tentu seperti itulah yang terjadi sebenarnya. Jangan-jangan itu hanyalah ou-topos dan bukan eu-topia; sesuatu yang tidak ada dan bukannya sesuatu yang dirindukan. Bahwa ketika rakyat memilih 
seorang pemimpin, pada saat itu sebetulnya yang dipilih adalah seorang yang telah “disiapkan” oleh segelintir orang yang menominasikannya. Siapa pun yang terpilih, para elit politik telah siap dengan "ongkos politik" yang telah diperhitungkan. Jelas, walaupun rakyat yang memilih namun pada saat itu, kepentingan elit politiklah yang dilayani. Inilah ketika Vox populi vox Dei menjadi sebuah isapan jempol belaka.

Dengan demikian, demokrasi yang dihidupi saat ini bukan soal suara terbanyak, bukan juga soal mayoritas-minoritas ataupun persoalan pemenang mengambil semua bagian (winner-takes-all), namun soal menguasai alur cerita sebuah pemerintahan. Menjadi tidak penting siapa yang berada di tampuk kepemimpinan, namun siapa yang berada di balik itu semua dan merancang skema percaturan politik. Dan ketika ia menguasai lingkaran terdekat dari pemimpin sebuah negara, maka ia pun akan mampu untuk mengarahkan kebijakan publik yang dikeluarkan oleh pemerintah. Rakyat pada titik ini, hanyalah menjadi penonton dari dagelan politik yang dimainkan.

Penelitian Gilens dan Page mengenai pemilihan umum dan pengaruhnya terhadap kebijakan publik di Amerika memberikan hasil yang cukup mencengangkan. Bahwa pengaruh suara rakyat sangat tidak signifikan dibandingkan dengan kepentingan para pemilik kapital yang berada di sekitar lingkaran penguasa. Gilens dan Page menuliskan demikian,

When the preferences of economic elites and the stands of organized interest groups are controlled for, the preferences of the average American appear to have only a minuscule, near-zero, statistically non-significant impact upon public policy... All in all, we believe that the public is likely to be a more certain guardian of its own interests than any feasible alternative. ${ }^{8}$

Gilens dan Page menemukan bahwa para penyokong dana kampanye dan pemilu para calon terpilihlah yang kemudian memiliki keuntungan paling besar, yaitu ketika bisnis dan usahanya bertambah berkali lipat seiring dengan kebijakan publik negara yang ramah terhadap usaha mereka. Memakai teori ini, maka piramida kekuasaan menjadi semakin jelas, bahwa terjadi ketidaksetaraan dalam berdemokrasi di Amerika, bahkan juga Indonesia! Ketika mereka yang memiliki kapital dan pengaruh terhadap pemerintahan memiliki posisi yang lebih tinggi, bahkan dari rakyat sekalipun. Demokrasi tidak lagi menjadi alat yang memberikan keuntungan bagi 
rakyat sebanyak-banyaknya, namun sebanyak-banyaknya keuntungan bagi pemilik kekuasaan. "Democracy is inequality!"

Sehingga tidaklah keliru ketika rakyat memberikan hak pilihnya, maka pada saat itu rakyat kehilangan haknya dalam ikut merancang arah negara ini. Rakyat telah memberikan "mandat" bagi segelintir orang untuk menentukan nasib orang banyak. Rakyat atau demos sebagai sebuah kekuatan atau kratos dalam demokrasi menjadi luluh pada saat itu juga dan berubah menjadi elitokrasi. Martel sembari mengutip Rousseau mengatakan,

The demos, the core of what democracy is supposed to be about, is held as dangerous, untruly - even (perhaps especially) anarchist. All the verbal support given to democracy hides its opposite, a desire for elite control, for "cooling [read suppressing] the passions' of the many and for refining the chaotic multitude via the medium of representation, which is really just a form of control and of inclusion in name alone. Thus, when we vote for our representative officials, we are, as Rousseau informs us, actually choosing our own exclusion from politics. ${ }^{9}$

Atas nama keteraturan dan legislasi, rakyat kemudian harus tunduk pada para mandataris yang sebetulnya mewakili rakyat. Dengan demikian, alur yang tercipta menjadi terbalik, para penerima mandat mengatur dan menguasai para pemberi mandat. Dan pemberi mandat menjadi "minoritas" dibanding penerima mandat yang kemudian menjadi "mayoritas" dalam hal pengaruh. Pada titik ini demokrasi menghancurkan persamaan dan kesederajatan.

Ironisnya, kondisi ini diperkuat oleh meningkatnya jumlah warga yang apatis terhadap masa depan politik dan demokrasi. Brennan, misalnya, melihat bahwa dalam berpolitik, corak manusia sangat beragam, ada yang memiliki pendapat akan banyak hal namun ada yang tidak berpendapat sama sekali alias apatis. Ada yang memiliki pendapat tak berubah selama bertahun-tahun namun ada juga yang memiliki pendapat cukup cair. Melihat fenomena ini, Brennan mencoba mengelompokkan masyarakat menjadi tiga kelompok, yang ia sebut sebagai "Three species of democratic citizens", yaitu Hobbits, Hooligans, dan Vulcans. ${ }^{10}$

Hobbits adalah kelompok orang yang apatis dan acuh terhadap politik. Mereka lebih memilih menghidupi hidup keseharian mereka tanpa memikirkan perihal politik sama sekali. Hooligans adalah kelompok orang yang mencintai politik, dan senang berbicara mengenainya. Namun seperti sebuah "hooligans" 
mereka cenderung mendengarkan diri mereka sendiri dan menutup kuping terhadap pendapat yang lain. Menurut Brennan, mereka yang bergerak dibidang politik, aktivis, anggota partai berada dalam kelompok ini. Terakhir, Vulcans adalah sekolompok orang yang secara saintifik dan rasional berbicara mengenai politik. Mereka berbicara berdasarkan data dan pengalaman dan bukan sekadar like and dislike. Kelompok ini telah "berhasil" mengatasi perbedaan dengan menghindari pelabel-an mereka yang berbeda dengan orang-orang bodoh atau tidak berpendidikan. ${ }^{11}$ Walau demikian, Brennan memberi catatan bahwa ini bukanlah polarisasi yang kaku, karena tidak ada seorang pun yang statis.

Untuk itu, pengelompokan yang dilakukan oleh Brennan perlu dicermati lebih dalam sebagai sebuah cerminan beragamnya "gaya berpolitik" dari setiap individu dalam sebuah negara. Bahwa pada kenyataannya, kelompok hobbits adalah mayoritas dalam kehidupan berpolitik kita yang ditunjukkan dengan rendahnya keikutsertaan masyarakat dalam pemilihan umum.

Ke-apatis-an dari masyarakat dalam mengikuti politik dan berdemokrasi juga tampak sebagai sebuah proses yang belum selesai dari demokrasi itu sendiri. Dalam studinya di negara-negara Amerika Latin, Calleros menunjukkan bahwa selepas dari rezim otoritarian, kini banyak negara di Amerika Latin mengalami masa transisi yang diwarnai dengan pranata hukum dan aparat penegak hukum belum sepenuhnya selesai dalam mereformasi dirinya. Keadaan incompleteness of the rule of law dalam demokrasi ini mengakibatkan negara dalam keadaan tidak stabil dan bisa saja memunculkan pemimpin yang otoriter untuk kedua kalinya. Terutama ketika masyarakat merasa bahwa kondisi yang dialami tidak jauh berbeda dengan masa otoritarian. Hal ini membuat masyarakat menjadi enggan untuk ikut dalam proses berdemokrasi, abai dalam menetapkan supremasi hukum sebagai tonggak perubahan. ${ }^{12}$ Jika melihat konteks Indonesia, bukan tidak mungkin demokrasi di Indonesia saat ini juga berada dalam keadaan yang sama, yaitu unfinished democracy dan mengakibatkan munculnya pihak-pihak yang dapat memanfaatkan keadaan tidak stabil ini. Dalam keadaan inilah muncul kembali wajah sang pemimpin otoriter sembari bertanya bernada menantang, "piye kabare? Enak jamanku to??" 
Sampai pada titik ini, kita melihat bahwa demokrasi sebagai sebuah proyek besar bersama berada dalam persimpangan akan kegagalan. Dan kegagalan ini adalah kegagalan sistemik yang membuka celah bagi sebagian orang untuk mengeksploitasinya. Demokrasi yang diharapkan menjadi mangkuk bersama setiap unsur masyarakat malah menghasilkan ketimpangan (inequality) dalam masyarakat semenjak ada sebagian kecil orang yang menguasai nasib orang banyak. Demokrasi pada titik ini mengalami "contradictio in terminis" karena justru rakyat dilemahkan dan menjadi "minoritas" dalam kekuatan suara; demos-kratos-less, artinya rakyat yang tidak memiliki kekuatan. Sehingga tidak sedikit masyarakat yang kemudian mengalami romantisisme sejarah dengan melihat kembali ke belakang dan lupa bahwa di zaman itu sebenarnya rakyat pun juga tidak berdaya. Dalam kondisi seperti ini, sumbangsih apa yang bisa diberikan kekristenan dan gereja secara khusus?

\section{Beriman dan Bergereja di Ruang Publik}

Kekristenan merupakan salah satu unsur pembentuk masyarakat dan hal ini tidak bisa diabaikan begitu saja. Dus, tanggung jawab sebagai pranata sosialkeagamaan yang turut di dalam proses berdemokrasi ada di pundak agama dan gereja juga. Kekristenan tidak bisa abai terhadap fenomena yang sedang menjerat kehidupan masyarakat, sebaliknya agama perlu menjadi peka dan responsif (bukan reaktif) terhadap kondisi riil. Bagi Volf, inilah kegagalan fungsi dari iman Kristen (malfunctions of faith) yang pertama, yaitu ketika iman berada dalam posisi diam (idleness of faith) dan tidak terkoneksi dengan kehidupan yang nyata. ${ }^{13}$ Iman yang hanya bergerak dalam satu lingkaran pasif tanpa berperan sebagai sebuah gaya hidup mengakibatkan iman menjadi gagal fungsi. Eka Darmaputera menyebut fenomena ini sebagai "gereja rumah hantu", yaitu ketika apa yang dialami di dalam gereja berbeda dengan apa yang digumuli di dalam kehidupan, jauh dari kebutuhan yang sebenarnya. Dan ini adalah akibat dari ketidakmauan memikul risiko dan tanggung jawab. ${ }^{14}$

Saya menafsirkan pendapat Volf dan Darmaputera ini sebagai manusia tersegregasi atau terbelah antara kehidupan iman di gereja sebagai "surgawi" dan kehidupan nyata di pekerjaan sebagai "duniawi." Kecenderungan melihat iman 
sebagai sebuah aktivitas di dalam diri pribadi tanpa ada dampak nyata adalah kegagalan iman yang besar. Rowan Williams mengatakan dengan tepat terkait hal ini, demikian

\begin{abstract}
A religious life is a material life. Forget for a moment the argument we might have about the definition of the 'spiritual life'; living religiously is a way of conducting a bodily life. It has to do with gesture, place, sound, habit - not first and foremost with what is supposed to be going on inside. The whole idea of an 'inner life' is, properly, what we put together from a certain reading of visible lives; it is not a self-evident category, a cluster of intangible experiences or mental dipositions, but what come to light as the sense, the intelligibility of a certain pattern of acts. ${ }^{15}$
\end{abstract}

Dengan demikian, menjadi orang yang beriman (people of faith) adalah menjadi orang yang secara utuh menghadirkan dirinya. Pameo "agama dan politik tidak boleh disatukan" sebenarnya adalah kegagalan agama (dan iman) dalam menunjukkan wajah yang merengkuh kemanusiaan. Bahwa dalam berpolitik dan berdemokrasi dibutuhkan manusia yang beriman pula! Politik tanpa iman dalam politik yang penuh dengan ketamakan, kerakusan, dan haus akan kekuasaan. Dan inilah yang terjadi saat ini.

Namun, Volf juga mengingatkan bahwa perlu diperhatikan bentuk kedua dari kegagalan fungsi iman, yaitu pemaksaan akan iman (coerciveness of faith). Berkebalikan yang pertama ketika iman diam tanpa aksi kali ini iman menunjukkan dirinya yang hiperaktif. Ini adalah tantangan dari pengakuan diri sebagai agama yang profetis dan mencoba mengubah dunia untuk tidak terjebak pada titik ini. Gejala ini oleh Magnis-Suseno disebut sebagai agamaisasi politik, yaitu ketika sebuah agama memaksakan keputusan sesuai dengan ajarannya saja. ${ }^{16}$

Lanjut Volf, kekristenan mengandung sebuah nilai yang penting dalam kehidupan bersama yaitu ketika kekristenan memiliki visi bahwa melalui dirinya dan pesan Yesus secara khusus - kehidupan orang lain menjadi bertumbuh dan berkembang. ${ }^{17}$ Identitas Kristen tidak menjadi penghalang akan perbedaan, namun sebaliknya identitas itu mengakui bahkan merengkuh perbedaan sebagai sesuatu yang inheren dalam tubuh iman Kristen. Volf menegaskan,

If Christian identity matters, then difference must matter as well. In the most general sense, get rid of difference and what remains will be nothing - you yourself, along with everything else, will be drowned in the sea of 
undifferentiated "stuff." To erase difference is to undo the creation, that intricate pattern of separations and interdependencies that God established when the universe was formed out of no-thing. Literally, every-thing depends on difference. $^{18}$

Pada titik ini, kekristenan seharusnya tidak menjadi resah akan partikularitas di tengah universalitas. Namun justru identitas Kristen-lah yang menyuarakan akan mempertahankan keunikan dalam derasnya arus pertemuan dengan yang lain perlu disuarakan lebih lantang. Bahwa agama tidak menjadi tembok pemisah namun sebagai tenaga pendorong yang menumbuhkan yang lain.

Dalam terang ini, maka menjadi teramat penting untuk memaknai kembali iman dan kehadiran gereja bukan sekadar sebagai sebuah entitas politis yang dapat mempengaruhi kebijakan publik dari pemerintah namun sebagai sebuah komunitas penggagas perubahan. Komunitas yang di dalamnya harkat dan martabat manusia dijaga bahkan diperjuangkan. Rowan Williams menegaskan hal ini, demikian

The presence of the Church, not as clamorous interest group but as a community confident of its rootedness in something beyond the merely political, expresses a vision of human dignity and mutual human obligation which...poses to every other community a special sort of challenge...In short, the significance of the Church for civil society is in keeping alive a concern both to honour and to justify the absolute and non-negotiable character of the human vision of responsibility and justice that is at work in all human association for the common good. It is about connecting the life of civil society with its deepest roots, acknowledged or not. ${ }^{19}$

Gereja pada arus politik yang deras tentu tidak boleh luluh dan terbawa arus, namun sebaliknya gereja perlu menjadi "suara penyeimbang" akan kedegilan arus pertarungan kekuasaan. Meminjam istilah biblis, gereja seperti Yohanes yang berseru-seru di padang gurun; vox clamantis in deserto. Suara yang nyaring dan meresahkan para penguasa karena lalai dan abai dalam memelihara rakyat sebagai pemegang mandat pemerintahan. Dengan demikian, posisi gereja senantiasa dirindui oleh masyarakat semenjak gereja menyuarakan narasi pinggir yang secara nyata bertatap muka dengan narasi besar yang disiapkan oleh pemerintah. Karena ketika gereja menjadi tak bersuara maka ia pun menjadi tidak berguna selain menjadi tempat pelarian akan penatnya dunia. Gereja menjadi kumpulan para eskapis, terputus dari dunia. Bonhoeffer menegaskan hal ini terkait pentingnya gereja untuk bersuara,

We have been silent witnesses of evil deeds; we have been drenched by many storms; we have learnt the arts of equivocation and pretence; experience has 
made us suspicious of others and kept us from being truthful and open; intolerable conflicts have worn us down and even made us cynical. Are we still of any use? ${ }^{20}$

Pada titik ini kita melihat bahwa ketika kekuasaan dan bukan kemanusiaan yang menjadi bahasa bersama dari masyarakat maka niscaya ide bersama dalam mengusahakan kemakmuran bagi setiap orang tidak akan pernah tercapai. Berkaca dari tantangan Bonhoeffer akan gereja yang digerus oleh arus dunia ini dan cenderung menjadi diam, kita perlu melihat kembali kiprah gereja sebagai GEREJA. Bahwa GEREJA adalah sebuah komunitas yang senantiasa berjuang melepaskan dirinya dan masyarakat di sekitarnya dari "sangkar emas" yang mengungkung kedua pihak ini. Kenyamanan sebagai sebuah entitas agamis yang lepas dari permasalahan dunia memang mengasyikkan namun itu berarti membohongi ciri fundamental gereja, yaitu gereja senantiasa menjadi komunitas pembebas. Seperti yang diungkapkan Harahap, bahwa gereja perlu melihat dirinya sebagai liberatio communio. Ia mengatakan,

...liberatio communio means viewing it as a dynamic entity, continually in motion, living in the creative tension between a peccatorum communio (community of sinners) and a sanctorum communio (community of saints). That is, a liberatio communio exists in a process of becoming church that gradually liberates the other and oneself, a position lying between being-church and doing-church...liberatio communio, a new way of being church that places the church in creative tension, especially in the midst of trouble and oppression. In particular, Majority World churches may in this way clearly identify themselves as the body of Christ. ${ }^{21}$

Hanya dengan membentuk dirinya sebagai komunitas pembebas-lah kemudian gereja dapat ikut serta dalam gerakan besar Allah dalam missio dei. Karena Allah secara nyata membentuk gereja sebagai sebuah entitas historis yang berjuang dalam menyuarakan pesan Kristus. Gereja adalah Kristus dan gereja adalah komunitas historis yang menjejakkan kaki di nusantara ini. Di dalam gereja kemudian entitas ini melebur menjadi satu. ${ }^{22}$ Dalam bahasa Williams, hal ini menjadikan umat di dalam gereja adalah para penjaga perjanjian (promise-keepers) yang dalam keterbatasan identitasnya, kita berada bersama dalam arak-arakan menuju sang pencipta yang sama pula. ${ }^{23}$

Hal ini jugalah yang Bonhoeffer sebut sebagai sebuah tindakan mengikuti Yesus. ${ }^{24}$ Bahwa Yesus yang menyejarah itu bukan sekadar sosok yang hidup dan 
nyata, atau sebagai guru moral yang tertinggi. Namun mengikuti Yesus sebagai seorang murid berarti menerima panggilan-Nya untuk menyatakan akan kasih dan kisah-Nya dalam kehidupan kita yang nyata. Kita dipanggil dalam kehidupan dan keseharian, bukan dalam keterpisahan dan kesendirian. Mengenai hal ini Bonhoeffer menulis,

If Jesus said: leave everything else behind and follow me, leave your profession, your family, your people, and your father's house, then the biblical hearer knew that the only answer to this call is simple obedience, because the promise of community with Jesus is given ti this obedience. But we would say: Jesus's call is to be taken "absolutely seriously," but true obedience to it consists of my staying in my profession and in my family and serving him there, in true inner freedom. Thus Jesus would call: come out! - but we would understand that he actually meant: stay in! - of course as one who has inwardly come out. ${ }^{25}$

Pendapat Bonhoeffer ini kemudian diikuti oleh ungkapannya yang terkenal, "cheap grace" dan "costly grace". Bagi Bonhoeffer, "cheap grace is the mortal enemy of our church. Our struggle today is for costly grace." 26

Tulisan Bonhoeffer ini menjadi penting bagi kita dalam jeratan demons-kratos karena disaat yang sama, Bonhoeffer sedang mengalami banyaknya pengunjung gereja yang merasa nyaman dengan kediktaktoran dan kekejaman Hitler. Anugerah yang diterima oleh umat tidak diikuti oleh tindakan kepatuhan terhadap Kristus yang mengejawantah dalam karya. Bahwa kebebasan yang dianugerahkan oleh Kristus bukanlah sesuatu yang seharusnya dinikmati sendiri, namun sebuah kualitas hidup yang seharusnya menjangkau yang lain melampaui dirinya sendiri. Dengan radikal Bonhoeffer menyatakan, "Christians are not only to have peace, but they are to make peace...choosing to suffer instead of causing others to suffer." 27 Seperti inilah bentuk nyata menjadi umat pembebas itu.

\section{KESIMPULAN}

Pada akhirnya kita perlu bertanya, apakah demokrasi yang sebagai sebuah sistem pemerintahan yang, seharusnya, menampung setiap golongan betul-betul akan membawa kita pada eu-topia ataukah ou-topia? Demokrasi di Indonesia, menurut saya, berada dalam persimpangan pasca runtuhnya Soeharto dan Orde Baru. Era Reformasi sebagai sebuah era yang diharapkan lebih menjunjung tinggi harkat dan martabat manusia pun ternyata belum berhasil. Kita berada dalam kondisi demokrasi 
yang urung usai (un-finished democracy) dan memang proses menuju masyarakat yang demokratis itu tidak akan pernah usai karena senantiasa akan ada pihak-pihak yang mencoba untuk menguasai yang lain.

Dalam konteks inilah kehadiran gereja di ruang publik yang membawa pesanpesan luhur menjadi penting. Gereja menegaskan bahwa kita menuju pada eu-topia, sebuah kondisi yang diimpikan bersama. Dan untuk itu gereja perlu menyuarakan beberapa hal yang sejatinya mengakar dari identitas gereja dan iman Kristen itu sendiri, yaitu perjuangan akan kesetaraan (equality), tanggung jawab moral, dan identitas diri yang utuh.

Perjuangan gereja dalam demokrasi kemudian bukan menjadi perjuangan akan kebenaran atas yang lain, karena itu akan menjadikan dirinya sebagai agamisasi politik - meminjam istilah Magnis-Suseno - namun sebuah perjuangan kemanusiaan dan keadilan. Ketika gereja bicara dalam tataran nilai kemanusiaan, maka tidak ada satu pun nilai lain yang akan menegasikannya, justru dukungan dan afirmasi akan mengikuti. Kesetaraan bicara mengenai memanusiakan manusia yang seharusnya berada pada tempat yang tepat. Demokrasi saat ini justru memakai manusia yang lain sebagai alat mencapai kekuasaan. Bukan manusia yang dilayani namun keinginan untuk berkuasalah yang dipentingkan. Pada titik ini, gereja perlu menyatakan dirinya sebagai gereja yang merengkuh manusia karena "all men are created equal." Inilah yang disebut sebagai "public church."

Tidak hanya memperjuangkan kemanusiaan, gereja juga perlu mengutus umat beriman ke tengah dunia dalam usaha berdemokrasi dengan baik. Praktik demokrasi dan politik praktis tidak hanya membutuhkan manusia yang memiliki kapabilitas namun juga memiliki moral sebagai alat penimbang keputusan. Inilah yang disebut sebagai "public faith." Bahwa umat beriman yang diutus tadi akan merasa resah akan ketidakadilan dan kemudian "meresahkan" para penguasa dengan kritik-kritik tajam namun penuh kedamaian. Gereja perlu mendorong umatnya untuk mengambil tindakan damai untuk mengembalikan bayangan akan eu-topia itu. Dan dengan demikian, maka gereja pun menjadikan umatnya memiliki identitas yang utuh. Iman 
tidak mengalami malfungsi namun iman betul-betul berdampak pada kehidupan demokratisasi di Indonesia.

Untuk mengkritik penyalahgunaan sistem demokrasi yang saat ini tidak lagi "demos-kratos" namun "demons-kratos" maka gereja perlu menjadikan dirinya sebagai tenaga penyeimbang. Itu berarti menjadikan dirinya dikenal dan dirasakan oleh publik. Melalui jembatan hermenutika di atas maka kita melihat bahwa apa yang terjadi dalam diri demokrasi saat ini tidaklah tepat. Bahwa kekuasaan berada di tangan rakyat itu berarti kekuasaan digunakan untuk kepentingan sebanyakbanyaknya orang, bahkan setiap orang. Bukankah itu pesan yang perlu senantiasa digaungkan?

\section{Endnotes:}

\footnotetext{
${ }^{1}$ Susan Welch, ed., Understanding American Government (Boston: Wadsworth, 2012), 30.

${ }^{2}$ Robert P Borrong, "Cengkeraman Sang Gurita: Pergulatan Negara Dan Kekuasaan Dalam Proses Demokratisasi Di Indonesia,” Jurnal Teologi Proklamasi No.05/Th.3, no. Quo Vadis Indonesia? Quo Vadis Kekristenan? (February 2004): 4.

${ }^{3}$ Heather M Campbell, Advances in Democracy: From the French Revolution to the Present-Day European Union (New York: New Britannica Educational Publishing, 2011), xi.

${ }^{4}$ Campbell, 216-17.

${ }^{5}$ Robert John Ackermann, Agama Sebagai Kritik (Jakarta: BPK Gunung Mulia, 1997), 5.

${ }^{6}$ Andrew Bradstock and Christopher Rowland, eds., Radical Christian Writings: A Reader (Oxford: Blackwell Publishers, 2002), 232.

${ }^{7}$ Welch, Understanding American Government, 223.

${ }^{8}$ Martin Gilens and Benjamin I. Page, "Testing Theories of American Politics: Elites, Interest Groups, and Average Citizens," Perspectives on Politics 12, no. 03 (September 2014): 575-76.

9 James Martel, “Are We 'Post-Democratic'-or Have We Not (yet) Been Democratic at All?," Juncture 22, no. 3 (2015): 210.

${ }^{10}$ Jason Brennan, Against Democracy (Princeton: Princeton University Press, 2016), 1-3.

${ }^{11}$ Brennan, 1-6.

12 Juan Carlos Calleros, The Unfinished Transition to Democracy in Latin America (New York: Routledge, 2009), 180-82.

${ }^{13}$ Miroslav Volf, A Public Faith, How Followers of Christ Should Serve the Common Good (Michigan: Brazos Press, 2011), 10-16.

${ }^{14}$ Eka Darmaputera, "Rumah-Hantu," in Tuhan Dari Poci Dan Panci (Jakarta: BPK Gunung Mulia, 1979), 13-20.

${ }^{15}$ Rowan Williams, Faith in the Public Square (London: Bloomsbury Continuum, 2012), 313.

${ }^{16}$ Frans Magnis-Suseno, "Politisasi Agama Dan Masa Depan Demokratisasi Di Indonesia," Jurnal Teologi Proklamasi No.04/Th.2, no. Politik "Minoritas" Kristen Indonesia (September 2003): 56-57.

${ }^{17}$ Volf, A Public Faith, How Followers of Christ Should Serve the Common Good, 17-21.

${ }^{18}$ Volf, 95.

${ }^{19}$ Williams, Faith in the Public Square, 307.

${ }^{20}$ Robin W. Lovin, Christian Faith and Public Choices: The Social Ethics of Barth, Brunner, and Bonhoeffer (Philadelphia: Fortress Press, 1984), 138.
} 
21 Harahap, Yoshua Budiman Paramita. "Liberatio Communio: The Ecclesiological Identity of Sadrach's Javanese Community." International Bulletin of Mission Research 41, no. 3 (2017): 247248.

${ }^{22}$ Dietrich Bonhoeffer, Sanctorum Communio (London: Collins, 1963), 87-88.

${ }^{23}$ Williams, Faith in the Public Square, 223-24.

${ }^{24}$ Judul asli buku Dietrich Bonhoeffer adalah Nachfolge, yang secara harafiah berarti mengikuti atau tindakan mengikuti. Buku ini kemudian diterjemahkan dalam Bahasa Inggris dengan judul edar, "The Cost of Discipleship."

${ }^{25}$ Mark Thiessen Nation, Anthony G. Siegrist, and Daniel P. Umbel, Bonhoeffer the Assassin?: Challenging the Myth, Recovering His Call to Peacemaking (Grand Rapids: Baker Academic, 2013), 144.

${ }^{26}$ Geffrey B. Kelly and F. Burton Nelson, The Cost of Moral Leadership: The Spirituality of Dietrich Bonhoeffer (Grand Rapids: Wm. B. Eerdmans Publishing, 2003), 131.

${ }^{27}$ Kelly and Nelson, 138.

\section{DAFTAR PUSTAKA}

Ackermann, Robert John. Agama Sebagai Kritik. Jakarta: BPK Gunung Mulia, 1997. Bonhoeffer, Dietrich. Sanctorum Communio. London: Collins, 1963.

Borrong, Robert P. "Cengkeraman Sang Gurita: Pergulatan Negara Dan Kekuasaan Dalam Proses Demokratisasi Di Indonesia." Jurnal Teologi Proklamasi No.05/Th.3, no. Quo Vadis Indonesia? Quo Vadis Kekristenan? (February 2004): 5-21.

Bradstock, Andrew, and Christopher Rowland, eds. Radical Christian Writings: A Reader. Oxford: Blackwell Publishers, 2002.

Brennan, Jason. Against Democracy. Princeton: Princeton University Press, 2016.

Calleros, Juan Carlos. The Unfinished Transition to Democracy in Latin America. New York: Routledge, 2009.

Campbell, Heather M. Advances in Democracy: From the French Revolution to the Present-Day European Union. New York: New Britannica Educational Publishing, 2011.

Darmaputera, Eka. "Rumah-Hantu." In Tuhan Dari Poci Dan Panci. Jakarta: BPK Gunung Mulia, 1979. 
Gilens, Martin, and Benjamin I. Page. "Testing Theories of American Politics: Elites, Interest Groups, and Average Citizens." Perspectives on Politics 12, no. 03 (September 2014): 564-81.

Harahap, Yoshua Budiman Paramita. "Liberatio Communio: The Ecclesiological Identity of Sadrach's Javanese Community." International Bulletin of Mission Research 41, no. 3 (2017): 239-250.

Kelly, Geffrey B., and F. Burton Nelson. The Cost of Moral Leadership: The Spirituality of Dietrich Bonhoeffer. Grand Rapids: Wm. B. Eerdmans Publishing, 2003.

Lovin, Robin W. Christian Faith and Public Choices: The Social Ethics of Barth, Brunner, and Bonhoeffer. Philadelphia: Fortress Press, 1984.

Magnis-Suseno, Frans. "Politisasi Agama Dan Masa Depan Demokratisasi Di Indonesia." Jurnal Teologi Proklamasi No.04/Th.2, no. Politik "Minoritas" Kristen Indonesia (September 2003): 56-64.

Martel, James. “Are We 'Post-Democratic'-or Have We Not (yet) Been Democratic at All?" Juncture 22, no. 3 (2015): 210-215.

Nation, Mark Thiessen, Anthony G. Siegrist, and Daniel P. Umbel. Bonhoeffer the Assassin?: Challenging the Myth, Recovering His Call to Peacemaking. Grand Rapids: Baker Academic, 2013.

Volf, Miroslav. A Public Faith, How Followers of Christ Should Serve the Common Good. Michigan: Brazos Press, 2011.

Welch, Susan, ed. Understanding American Government. Boston: Wadsworth, 2012.

Williams, Rowan. Faith in the Public Square. London: Bloomsbury Continuum, 2012 